窒化インジウム系半導体太陽電池の最近の動向と課題*

山本 暠勇*1,2・ブイヤン アシュラフル G.*3

\title{
Recent Progress and Challenges in InN-based Solar Cells
}

\author{
Akio YAMAMOTO*1,2 and Ashraful G. BHUIYAN*3 \\ ${ }^{* 1}$ Graduate School of Engineering, University of Fukui, 3-9-1 Bunkyo, Fukui-shi, Fukui 910-8507, Japan \\ *2JST-CREST, 7 Gobanchyo, Chiyoda-ku, Tokyo 102-0075, Japan \\ ${ }^{*}$ Faculty of Electrical \& Electronic Engineering, Khulna University of Engineering and Technology, Khulna-9203, Bangladesh
}

(Received May 7, 2012, Accepted September 26, 2012)

\begin{abstract}
The revision of InN bandgap to a much narrower value $(\approx 0.7 \mathrm{eV})$ has opened the new research on InN-based solar cell. For InNbased materials, multi-junction solar cell seems to be the most promising approach, because a wanted bandgap between 0.6 and $2.5 \mathrm{eV}$ can be obtained by using the alloy materials. Many groups have reported homojunction-type or sandwich-type InGaN solar cells. The maximum In content in InGaN absorption layers employed is around $0.3\left(\mathrm{E}_{\mathrm{g}} \approx 2.3 \mathrm{eV}\right)$. The low In content is the main reason for the poor performance of the present single-junction devices under the solar irradiance. To realize a high efficiency multi-junction cell, many issues, especially, the growth of high quality alloy films with an In content of $0.4-1$ and the control of p-type doping, should be solved.
\end{abstract}

\section{1. はじめに}

高効率太陽電池を実現するうえで最も有力な方法はタンデ ム構造の実現である.タンデム構造とは，バンドギャップの 異なる太陽電池（以後, サブセルと呼ぶ）を複数用意し, 光 の入射側からバンドギャップの大きいサブセルの順に積層し たものを言う。このような構造を形成することによって，太 陽光スペクトル中のエネルギーの大きい光子から順に篩で選 り分けるように利用することができ，多くの光子を利用でき ることのみならず, 光子 1 個が持つエネルギーをより有効 に利用することができる.すなわち, 太陽光エネルギーの有 効利用（変換効率の向上）が図られることになる.

最近, 窒化インジウム $(\mathrm{InN})$ 系の窒化物半導体が新たな タンデム太陽電池用材料として注目されるようになってき た. それは, InNの禁止帯幅がこれまで長く信じられてきた 約 $2 \mathrm{eV}$ とは大きく異なる約 $0.7 \mathrm{eV}$ であることが明らかとな った1)ためである.

本稿では, タンデム太陽電池材料としての InN 系窒化物

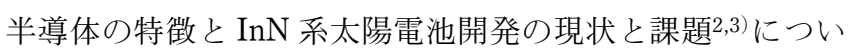
て紹介する。

\section{2. 太陽電池用材料としての窒化物半導体の特徵}

Fig. 1 は, 代表的な半導体材料のバンドギャップと格子 定数との関係 2 を示したものである. タンデム太陽電池用材 料としてはバンドギャップ0.6 2.5 eVの半導体材料が必要 となる. Fig. 1 に示すように, $\mathrm{InN} と \mathrm{GaN}$ あるいは $\mathrm{AlN}$ と で形成される混晶InGaN, InAlNを用いて $0.7 〜 2.5 \mathrm{eV}$ の間 の任意のバンドギャップを実現できることが明らかとなっ

* 平成23年11月25日 日本真空学会2011年11月研究例会で発表

*1 福井大学大学院工学研究科 (干910-8507 福井市文京 3-9-1)

*2 科学技術振興機構 戦略的創造研究推進事業 (CREST) (T1020076 東京都千代田区五番町 7)

*3 クルナ工業技術大学電気電子工学部(クルナ-9203, バングラ ディッシュ)

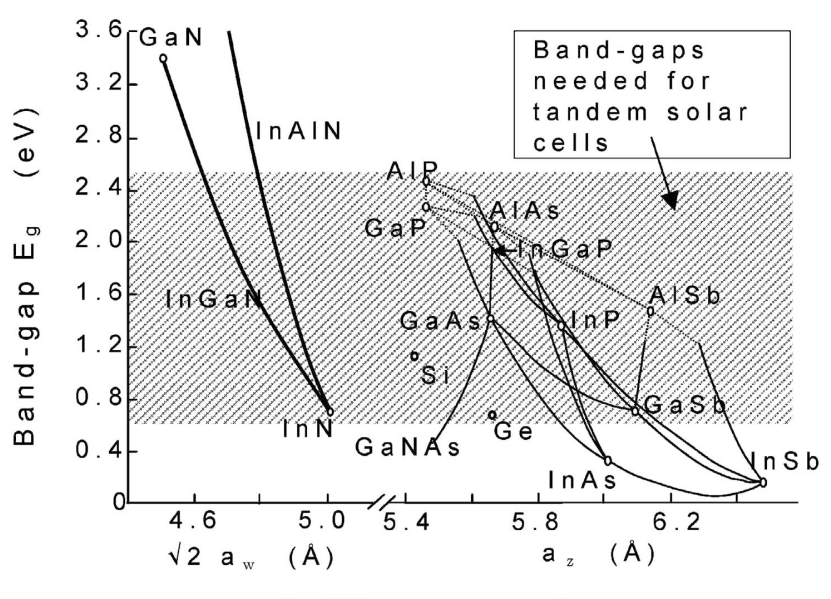

Lattice parameter

Fig. 1 Relationships between band-gap energy and lattice parameter for the conventional IV, III-V, and nitride semiconductors. Dashed area shows the region of band-gaps needed for tandem solar cells.

た.すなわち, 組成の異なる InGaN や InAlN を用いてサブ セルを多数形成することが可能となり, 理想的なタンデム太 陽電池の実現が期待されるようになった。

これまでに開発されているタンデム太陽電池の代表例は $\mathrm{InGaP} / \mathrm{GaAs} / \mathrm{Ge}$ 系 3 接合太陽電池 ${ }^{4)}$ であり, 非集光下で30 $\%$ 以上, 集光下で $40 \%$ 以上という高効率がすでに実現され ている. しかしながら, このタンデム太陽電池の課題は, 各 サブセル間の電流不整合が大きいことである，具体的には，

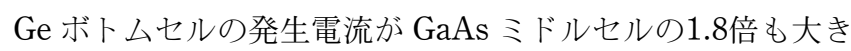
い.すなわち, サブセルが直列に接続されるこの構造では, 3 つのサブセルの発生電流のうち最少の発生電流がタンデム セルの発生電流となるため, Ge ボトムセルでの発生電流の 約半分が使われないことなる. 従って, その改善策として は, ミドルセル材料のバンドギャップを小さくしてミドルセ ルでの発生電流を増大させるか, ボトムセル材料として Ge 
よりもバンドギャップの大きな材料を使用し発生電流を減ら す代わりに発生電圧を上げるという対策を講ずることであ る．これができれば，更なる高効率化が可能となる，そのよ うな観点から, 電流不整合を低減するために敢えて格子不整 合を導入するという方向での検討が進んでいる. その結果, サブセル間には，1〜2\%の格子不整合 ${ }^{5,6)}$ が存在している. このような格子不整合系の素子は未だ発展途上であるといえ るが，すでに格子整合系を上回る43.5\%（418倍集光下）と いう高変換効率が実現されている7). この材料系において, 上記の電流不整合の問題を解消するとともに，4 接合化を狙 う方法としてバンドギャップ $1 \mathrm{eV}$ の GaInAsNの利用が提 案された8)が, GaInAsN 薄膜の高品質化が難しく, 未だ実 現には至っていない.

InGaN, InAlN などの InN 系混晶半導体の特徵は $0.7 〜 3.4$ $\mathrm{eV}, 0.7 \sim 6.2 \mathrm{eV}$ の範囲で連続的に任意のバンドギャップが 実現できることであり, タンデム太陽電池を形成する場合, サブセル間の電流整合が実現できるバンドギャップが容易に 選択できることになる．そのような多接合太陽電池の出力特 性を簡単に見積ることにする．ここでは，AM1.5の太陽光 スペクトルを用いるとして, 縦軸を光子数, 横軸を光子エネ ルギーで表した AM1.5スペクトルを用意する．短絡電流密 度 J sc，開放端電圧 Voc を次のような方法で算出する。 $\mathrm{n}$ サ ブセルから成るタンデム太陽電池を例にすると, 太陽光スペ クトルのうち $0.7 \mathrm{eV}$ 以上のエネルギーを有する光子数を積 算し，それが $\mathrm{n}$ 等分される光エネルギーを求める.これに よって電流整合が実現できる各サブセルの禁止帯幅 $\mathrm{Eg}$ が決 定されることになる. 次に, $\mathrm{n}$ 等分された光子数に電子電荷 量 q を乗じたものを各サブセルの理想的な Jsc と考える．こ れは, 各サブセルに入射した光子のうち禁止帯幅以上のエネ ルギーを有するものはすべて光電流に寄与することを意味す る. 即ち, 収集効率 $100 \%$ である. 今回の計算では, 実際に 近い值を得るために，平均收集効率として0.9を乗じたもの をJscとした．各サブセルのV Voc の算出には，よく知られ た経験式， $\mathrm{Voc}=\mathrm{Eg} / \mathrm{q}-0.4(\mathrm{~V})$ ，を用いた．タンデム太陽 電池のVoc は n 個のサブセルのVocの総和となる．加え て，ここでは計算結果をより実際的なものとするため, 曲線 因子 FF として0.85の值を用いて出力電力を求めた. このよ うにして求めたサブセル数 10 までのタンデム太陽電池の出 力特性を Fig. 2 に示す. Fig. 2 の結果からわかるように, 6 接合のタンデム太陽電池では約 $50 \%$ の変換効率と $5 \mathrm{~V}$ を超 える開放端電圧が期待される ${ }^{2)}$. 開放端電圧が高く短絡電流 密度が小さいこの種の太陽電池は集光動作においてその特徵 を発揮するものと考えられる．組成の異なる InGaN, InAlN を用いてタンデム太陽電池を作製する場合，各サブセル間に は格子不整合が存在する。例えば，バンドギャップ $0.7 \mathrm{eV}$ と $2.5 \mathrm{eV}$ の材料を実現する場合, InGaN 系では $7.6 \%$, In$\mathrm{AlN}$ 系で $4 \%$ の格子不整合が存在する. 両者の間に中間の格 子定数を有するサブセルを挿入し，5 接合タンデムタンデム 太陽電池を構成するならば，各サブセル間の格子不整合は， それぞれ，平均 $1.5 \%, 0.8 \%$ となり， InGaP $/ \mathrm{InGaAs} / \mathrm{Ge}$ 系 の例から考えて，これらは克服できない不整合率ではないと 考えられる.さらにサブセル数を増加させれば格子不整合率
はさらに減少する. 従って, 接合数の増加は太陽光スペクト ルの利用効率の向上のみならず，サブセル間の格子不整合の 低減にもつながるという利点がある．Fig. 3 に，InGaN で 10接合タンデム太陽電池を作製する場合の予想されるバン ド図と各サブセル材料の組成を示す2).サブセルの組成は, Fig. 2 の計算で求められた禁止帯幅に基づき, InGaNの ボーイングパラメータ $1.43^{9)}$ を仮定して決定した．このよう に，実際のタンデム太陽電池では空層，Back surface field (BSF) 層やトンネル接合層が必要となり，構成としてはか なり複雑なものとなる.

一般に, 単一接合の太陽電池に対する最適のバンドギャッ

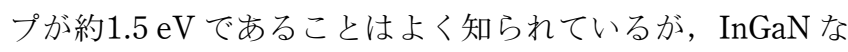
どの窒化物半導体を用いて単一接合太陽電池を開発すること は得策とは言えない。何故ならば，バンドギャップが約 1.5 $\mathrm{eV}$ の材料としては GaAs や CdTe が存在し，これらの材料 による高効率太陽電池がすでに開発されているからである. すなわち, 単一接合太陽電池においては, $\mathrm{InN}$ 系半導体太陽 電池は混晶成長プロセスの複雑さや原料コストの面から，そ の優位性を発揮するのは難しいと考えられる．よって，窒化 物半導体太陽電池の特徵がタンデム化であることは言うまで もないが，先行技術である $\mathrm{InGaP} / \mathrm{InGaAs} / \mathrm{Ge}$ 系 3 接合タ ンデム太陽電池の存在・現状を考えると，4接合以上のタン

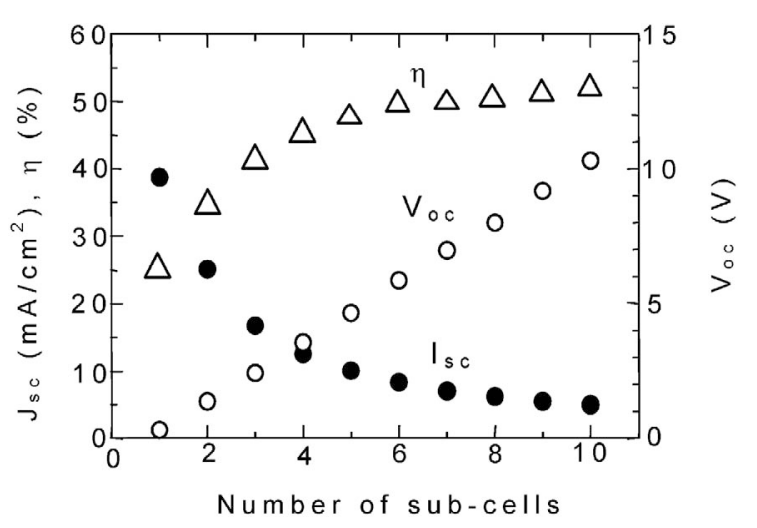

Fig. 2 Expected output performance for multi-junction tandem cells with a different number of sub-cells. A current generated in each sub-cell is assumed to be the same each other (the current matching is achieved).

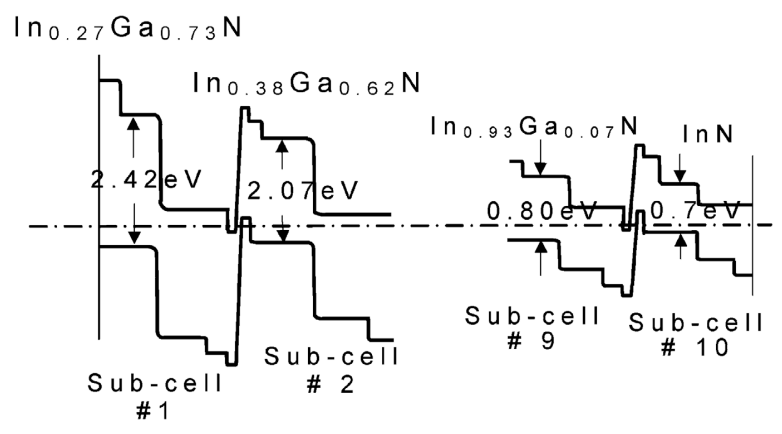

Fig. 3 Band diagram of a 10-junction tandem solar cell designed using InGaN so that the photo-generated current for each sub-cell is matched. Each sub-cell has a window layer, a back-surface field layer and is connected using a tunnel junction. 
デム太陽電池においてのみ，その存在意義を発揮できるもの と考えられる.

\section{InN 系窒化物半導体太陽電池開発の現状}

\subsection{InGaN, InAlN 薄膜の成長技術}

タンデム太陽電池の作製に必要な $0.6 \sim 2.5 \mathrm{eV}$ のバンドギ ヤップを実現するためには, In 組成 $1 \sim 0.3$ InGaN, In 組 成 $1 \sim 0.5$ の InAlNを作製する必要がある。これまでに, MOCVD 法を中心に, GaN については成膜技術や pn 接合 技術が進んでいるが，三元混晶の成長，特に，中間組成域〜 In-richの材料の検討例はかなり少ない. 混晶成長において 最初に懸念されるのは相分離の問題であるが, InGaNに関 しては, 成長温度等の最適化により相分離を抑制することが できる10,11). Fig. 4 に MOVPE 法により成長させた InGaN 膜の $\mathrm{X}$ 線回折図形を示す ${ }^{11)}$. この結果から, In 組成 $0 \sim 0.8$ の範囲に渡って相分離や金属 In の析出のない InGaN 膜が形 成できていることがわかる. Fig. 5 は MOVPE 成長 InGaN の成長温度と In 組成との関係である ${ }^{11)}$. In 組成 0.4 以下の InGaN に対しては成長温度によって，0.4以上に対しては原

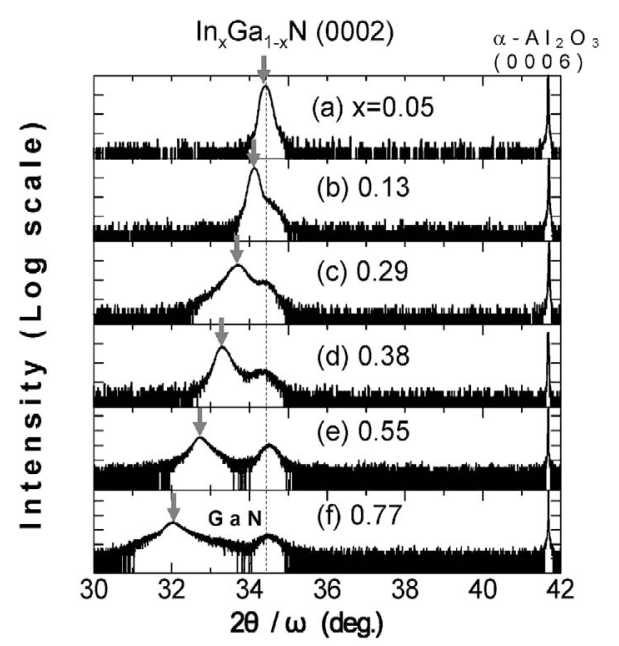

Fig. 4 X-ray diffraction $2 \theta / \omega$ profiles for MOVPE-grown InGaN with a different In content.

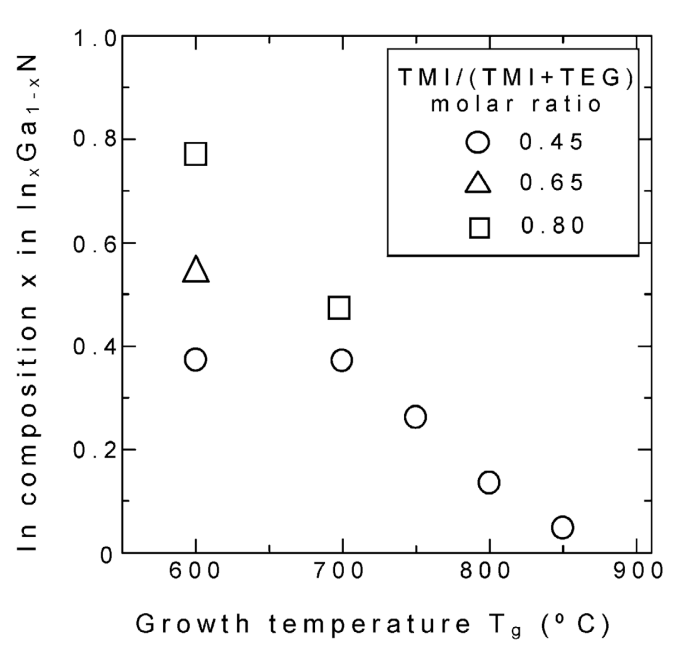

Fig. 5 In composition in InGaN grown at a different temperature with a different TMI/ (TMI + TEG) molar ratio.
料供給モル比 TMI/ (TMI+TEG) を変化させることによっ て, 成長膜のIn組成が制御されている。このように, InGaN についてはほぼ全組成域の混晶膜が得られる段階に 至っている.

通常, InGaN 膜の成長にはサファイア基板が使用される が, InGaN/Si2 接合タンデム太陽電池 ${ }^{12,13)}$ への興味から, Si (111) 基板上への InGaN 成長も最近検討されるようになっ た．Fig. 6 は $\mathrm{AlN}$ 層を中間層として $\mathrm{Si}(111)$ 基板上への InGaNの MOVPE 成長を検討した結果14)である．この結果 からわかるように， $\mathrm{Si}$ 基板上でもサファイア基板上と同様 に単結晶 InGaN 膜が形成できている. Fig. 7 は $\mathrm{GaN} / \alpha-$ $\mathrm{Al}_{2} \mathrm{O}_{3}(0001)$ テンプレート上抢よび $\mathrm{AlN} / \mathrm{Si}$ (111) 上に成長 させた InGaN 膜の X 線ロッキングカーブ半值幅の In 組成 依存性 ${ }^{14)}$ である。この結果からわかるように, InGaN 膜の

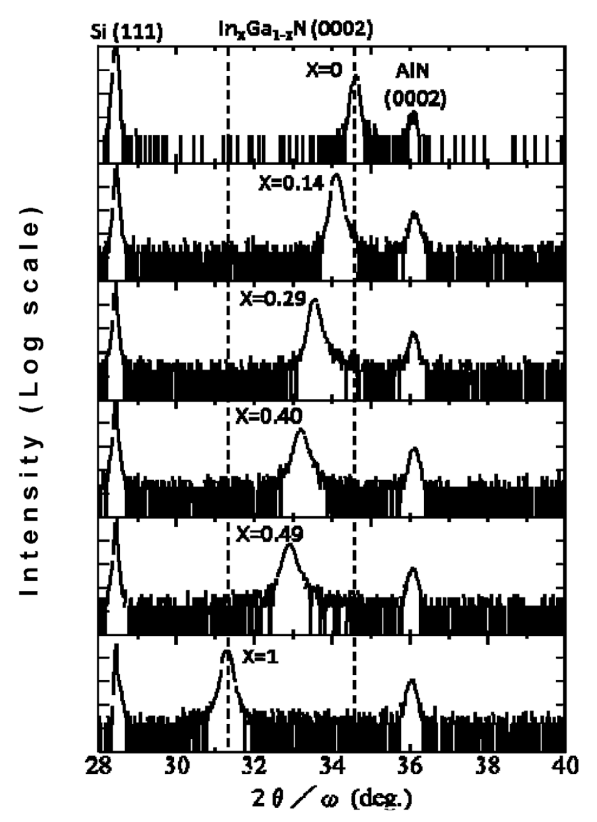

Fig. 6 X-ray diffraction $2 \theta / \omega$ profiles for MOVPE InGaN grown on $\mathrm{Si}(111)$.

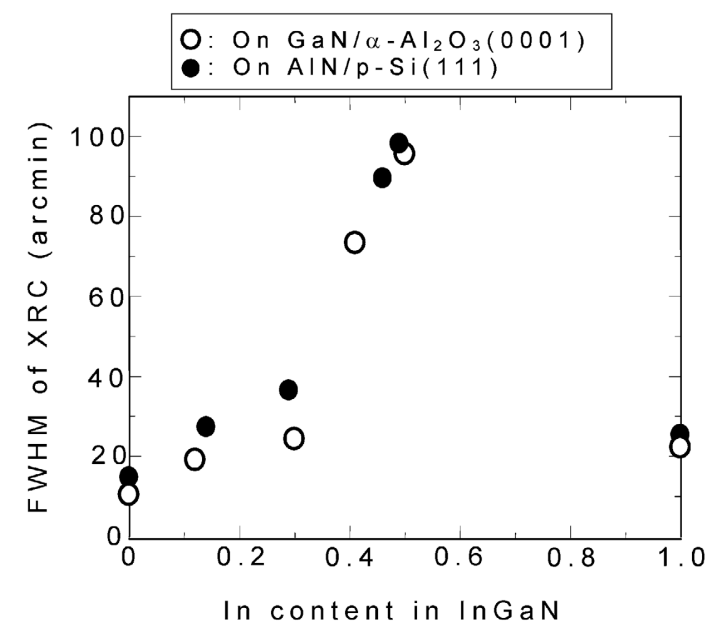

Fig. 7 FWHM of X-ray rocking curve (XRC) for the InGaN (0002) for samples grown on a different substrate with a different In composition. 
結晶性は In 組成に大きく依存しており，基板の種類に対す る依存性はあまり大きくない。すなわち, 格子不整合や下地 の結晶よりは InGaN 自体の性質が原因で In 組成 0.3 以上の 中間組成で結晶性が顕著に低下していると考えられ，混晶成 長の難しさを表しているものと考えられる．後述するよう に，現状では InGaN 系太陽電池としては In 組成約 0.3 まで しか実現されていないが，その原因は In 組成 0.3 以上での結 晶性の低下が主原因であると考えられる。

InGaN 系太陽電池の実現にとって, InGaN 膜成長の次の 課題が $\mathrm{p}$ 型ドーピングである．Fig. 8 は， InGaNの MOVPE 成長に拈いて原料としてビスシクロペンタジエニ ルマグネシウム $\left(\mathrm{Cp}_{2} \mathrm{Mg}\right)$ を用いて $\mathrm{InGaN} へ の ~ \mathrm{Mg}$ ドーピ ングを行った結果11)である。この結果からわかるように，In 組成0.4近くまでの InGaN において $\mathrm{p}$ 型伝導が確認されてい るが, $\mathrm{GaN}$ の場合と同様, $\mathrm{Mg}$ の高濃度ドーピングを行う と再度 $\mathrm{n}$ 型化するという現象がみられる。また， $10^{18} \mathrm{~cm}^{-3}$ 以上の正孔濃度が得られているが，これには In 組成の増加 とともに $\mathrm{Mg}$ アクセプターレベルが浅くなるという効果が 寄与しているものと考えられる.

以上示したように，In 組成 0.4 近くまでの InGaN におい て $\mathrm{p}$ 型伝導が実現されてはいるが， $\mathrm{p}$ 型伝導の再現性はもち ろん, $\mathrm{Mg}$ 濃度, 正孔濃度の制御性など, 未確立の課題は多 w.

一方, InAlN に関しては, TMA と $\mathrm{NH}_{3}$ のアダクト反応 の問題15) もあって MOVPE 成長の検討例が少なく，良質な 単結晶薄膜形成が実現されるまでには至っていない. Fig. 9 は MOVPE 法による InAlN 膜形成の結果の一例である16). この結果からわかるように, X 線回折ピークはかなりブ ロードではあるが In 組成 1 ～ 0.2 の InAlN 膜が形成されてい ることがわかる. InAlN の p 型化については 1 例のみ報告 例17)があるが，ほとんど未検討に近い状況である.

\subsection{InGaN 系太陽電池の研究状況}

$\mathrm{InN}$ のバンドギャップ值の見直しを受けて，2003年に InN 系材料の太陽電池への応用に関する提案 ${ }^{18)}$ があり，それ

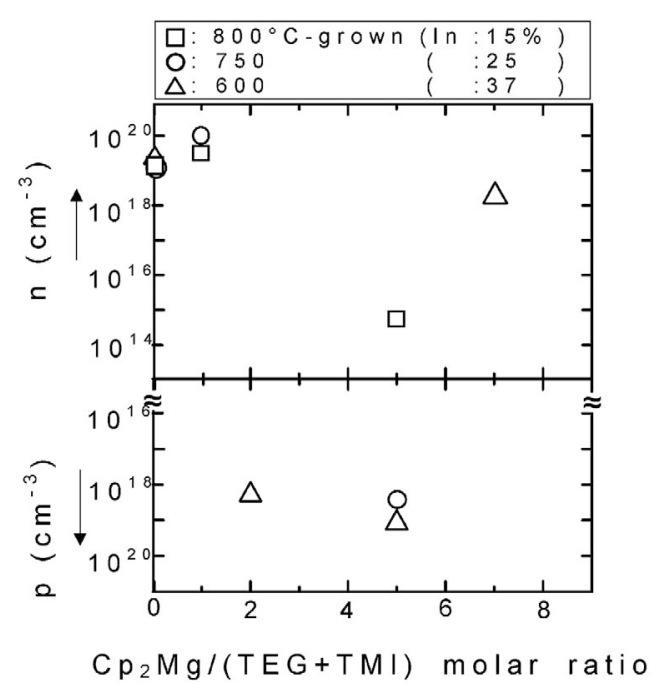

Fig. 8 Electron or hole concentration in Mg-doped InGaN as a function of $\mathrm{Cp}_{2} \mathrm{Mg} /(\mathrm{TEG}+\mathrm{TMI})$ molar ratio.

以後，太陽電池作製に関する報告が急激に増加した。これま でに検討されている窒化物半導体太陽電池は二種類に大別さ れる. Fig. 10にそれらを模式的に示した. 第一の種類は通 常のホモあるいはへテロ接合素子である。他のひとつはi$\mathrm{InGaN}$ や InGaN/GaN の量子井戸 $(\mathrm{QW})$, 超格子 $(\mathrm{SL})$ 層 等を $\mathrm{GaN}$ の pn 層で挟んだもの（Sandwich type）で，この 種の太陽電池の報告がかなり多い，その理由は，このような 素子構造は LED など発光素子の構造と基本的に同じであ り，すでに基本技術が存在するからであると考えられる．女

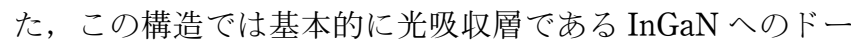
ピングが不要であるという利点もある. Table 1 にホモ接合 型素子19-28), Table 2 に Sandwich type 素子29-46)の報告例を 示す．両構造ともにMOVPE 法やMBE 法によって作製さ れているが，主流はMOVPE 法である. InGaNのホモ pn 接合素子の作製は, InGaN の厚膜化や $\mathrm{p}$ 型化が必要なため に報告例は必ずしも多くはないが，In 組成約 0.3 までの InGaN について報告されている. Fig. 11は $\operatorname{In}_{0.25} \mathrm{Ga}_{0.75} \mathrm{~N}$ 膜 を用い作製した $\mathrm{n}^{+}-\mathrm{p}$ 接合構造素子の構造と電流密度一電圧 特性 24 である. この場合, 光照射は $\mathrm{n}^{+}-\mathrm{InGaN}$ 側から行わ れた。この結果から明らかなように, ダイオード特性, 光起 電力が確認されるが, 変換効率は約 $0.2 \%$ と低く, 今後大幅

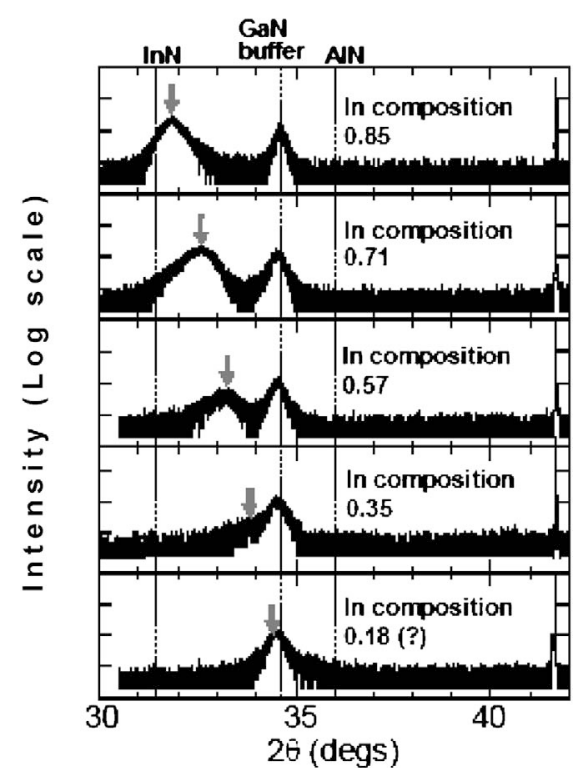

Fig. 9 X-ray diffraction $2 \theta / \omega$ profiles for MOVPE-grown InAlN with a different In content.

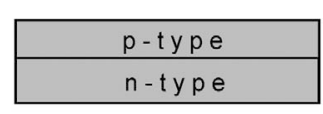

(a) Conventional homo- or hetero. junction type

ig. 10 Device structure for nitride semiconductor solar cells ever studied. 
Table 1 Reports on homojunction $\operatorname{In}_{\mathrm{x}} \mathrm{Ga}_{1-\mathrm{x}} \mathrm{N}$ solar cells.

\begin{tabular}{|c|c|c|c|c|}
\hline $\begin{array}{c}\text { Structure } \\
\text { (Growth Method) }\end{array}$ & In content (Thickness) & Voc and Jsc (Excitation) & $\begin{array}{l}\text { Year 1st } \\
\text { author }\end{array}$ & Reference \\
\hline p-n InGaN (MOVPE) & $0.18(320 \mathrm{~nm})$ & $0.43 \mathrm{~V}$ and $0.04 \mathrm{~mA} / \mathrm{cm}^{2}(360 \mathrm{~nm})$ & $\begin{array}{l}2007 \\
\text { Yang }\end{array}$ & {$[19]$} \\
\hline p-n InGaN (MOVPE) & $0.28(100 \mathrm{~nm})$ & $2.1 \mathrm{~V}$ (Light enhanced with UV) & $\begin{array}{c}2007 \\
\text { Jani }\end{array}$ & {$[20]$} \\
\hline p-i-n InGaN (MBE) & $0 \sim 0.3(800 \mathrm{~nm})$ & $2.5 \mathrm{~V}$ and $30 \mathrm{~mA} / \mathrm{cm}^{2}(\mathrm{GaN})\left(325 \mathrm{~nm} ; 200 \mathrm{~mW} / \mathrm{cm}^{2}\right)$ & $\begin{array}{l}2008 \\
\text { Chen }\end{array}$ & {$[21]$} \\
\hline p-n InGaN (MBE) & $0.31(700 \sim 1000 \mathrm{~nm})$ & $\begin{array}{l}0.55 \mathrm{~V} \text { and } 0.24 \mathrm{~mA} / \mathrm{cm}^{2}(\mathrm{AM} 0) ; 0.78 \mathrm{~V} \text { and } 1.99 \mathrm{~mA} / \\
\mathrm{cm}^{2}(3 \text { suns AM0) }\end{array}$ & $\begin{array}{l}2008 \\
\text { Misra }\end{array}$ & {$[22]$} \\
\hline p-n InGaN (MOVPE) & $0.12(300 \mathrm{~nm})$ & $1.5 \sim 2 \mathrm{~V}$ and $0.04 \mathrm{~mA} / \mathrm{cm}^{2}$ & $\begin{array}{r}2008 \\
\text { Jani }\end{array}$ & {$[23]$} \\
\hline p-n InGaN (MOVPE) & $0.25(700 \mathrm{~nm})$ & $1.5 \mathrm{~V}$ and $0.5 \mathrm{~mA} / \mathrm{cm}^{2}(\mathrm{AM} 1.5)$ & \begin{tabular}{c|}
2008 \\
Yamamoto
\end{tabular} & {$[24]$} \\
\hline p-i-n InGaN (MOVPE) & $0.02 \sim 0.15(400 \mathrm{~nm})$ & $2.24 \sim 0.96 \mathrm{~V}$ and $1.4 \sim 1.87 \mathrm{~mA} / \mathrm{cm}^{2}(\mathrm{Xe}$ Lamp$)$ & $\begin{array}{c}2009 \\
\text { Cai }\end{array}$ & $\begin{array}{l}{[25]} \\
{[26]} \\
\end{array}$ \\
\hline p-n InGaN (MOVPE) & $0.148 \sim 0.168(80 \mathrm{~nm})$ & $\begin{array}{l}1.73 \mathrm{~V} \text { and } 0.91 \mathrm{~mA} / \mathrm{cm}^{2}(\mathrm{AM} 0) ; 1.47 \mathrm{~V} \text { and } 0.26 \mathrm{~mA} / \\
\mathrm{cm}^{2}(\mathrm{AM} 1.5)\end{array}$ & $\begin{array}{c}2010 \\
\text { Jampana }\end{array}$ & {$[27]$} \\
\hline p-n InGaN (MBE) & $0.14 \sim 0.33(400 \sim 1000 \mathrm{~nm})$ & $1.8 \sim 0.2 \mathrm{~V}$ and $1 \sim 2.2 \mathrm{~mA} / \mathrm{cm}^{2}(\mathrm{Xe}$ Lamp$)$ & $\begin{array}{l}2011 \\
\text { Boney }\end{array}$ & {$[28]$} \\
\hline
\end{tabular}

Table 2 Reports on sandwich-type $\operatorname{In}_{\mathrm{x}} \mathrm{Ga}_{1-\mathrm{x}} \mathrm{N}$ solar cells.

\begin{tabular}{|c|c|c|c|c|}
\hline Structure (Growth Method) & $\begin{array}{l}\text { In content } \\
\text { (Thickness) }\end{array}$ & Voc and Jsc (Excitation) & $\begin{array}{l}\text { Year } \\
\text { 1st author }\end{array}$ & $\begin{array}{l}\text { Refer- } \\
\text { ence }\end{array}$ \\
\hline p-i-n GaN/InGaN/GaN (MOVPE) & $\begin{array}{l}0.04 \sim 0.05 \\
(200 \mathrm{~nm})\end{array}$ & $2.4 \mathrm{~V}$ (Light enhanced with UV) & $\begin{array}{c}2007 \\
\text { Jani }\end{array}$ & {$[29]$} \\
\hline p-i-n GaN/InGaN/GaN (MOVPE) & $0.12(200 \mathrm{~nm})$ & $1.81 \mathrm{~V}$ and $4.2 \mathrm{~mA} / \mathrm{cm}^{2}$ (concentrated $\left.\mathrm{AM} 0\right)$ & $\begin{array}{l}2008 \\
\text { Neufeld }\end{array}$ & {$[30]$} \\
\hline p-i-n GaN/InGaN/GaN (MOVPE) & $0.1(150 \mathrm{~nm})$ & $2.1 \mathrm{~V}$ and $0.46 \mathrm{~mA} / \mathrm{cm}^{2}(\mathrm{AM} 1.5)$ & $\begin{array}{l}2008 \\
\text { Zheng }\end{array}$ & {$[31]$} \\
\hline p-GaN/InGaN-GaN MQW/n-GaN(MOVPE) & $0.3(24 \mathrm{~nm})$ & $2 \mathrm{~V}$ and $1.5 \mathrm{~mA} / \mathrm{cm}^{2}$ (white light source) & $\begin{array}{l}2009 \\
\text { Dahal }\end{array}$ & {$[32]$} \\
\hline $\begin{array}{l}\text { p- } \text { In }_{0.1} 9 \mathrm{Ga}_{0.8} 1 \mathrm{nN} / \mathrm{InGaN}-\mathrm{GaN} \mathrm{SL} / \mathrm{n}-\mathrm{GaN} \\
\text { (MOVPE) }\end{array}$ & $0.25(84 \mathrm{~nm})$ & $1.4 \mathrm{~V}$ and $0.8 \mathrm{~mA} / \mathrm{cm}^{2}(\mathrm{AM} 1.5)$ & $\begin{array}{l}2009 \\
\text { Sheu }\end{array}$ & {$[33]$} \\
\hline p-GaN/InGaN-GaN MQW/n-GaN (MOVPE) & $\begin{array}{l}0.2(15 \mathrm{~nm}) \\
0.28(15 \mathrm{~nm})\end{array}$ & $\begin{array}{l}2.2 \mathrm{~V} \text { and } 0.66 \mathrm{~mA} / \mathrm{cm}^{2} 1.8 \mathrm{~V} \text { and } 1.09 \mathrm{~mA} / \mathrm{cm}^{2} \\
\left(\mathrm{AM} 1.5 ; 100 \mathrm{~mW} / \mathrm{cm}^{2}\right)\end{array}$ & $\begin{array}{l}2009 \\
\text { Jeng }\end{array}$ & {$[34]$} \\
\hline p-i-n GaN/InGaN/GaN Thin-film (MOVPE) & $0.1(150 \mathrm{~nm})$ & $2.09 \mathrm{~V}$ and $0.52 \mathrm{~mA} / \mathrm{cm}^{2}(\mathrm{AM} 1.5)$ & $\begin{array}{l}2009 \\
\text { Horng }\end{array}$ & {$[35]$} \\
\hline p-GaN/InGaN-GaN MQW/n-GaN (MOVPE) & $0.3(27 \mathrm{~nm})$ & $1.95 \mathrm{~V}$ and $0.83 \mathrm{~mA} / \mathrm{cm}^{2}$ (AM1.5) & $\begin{array}{c}2010 \\
\text { Lai }\end{array}$ & {$[36]$} \\
\hline p-i-n GaN/InGaN/GaN (MOVPE) & $0.08(150 \mathrm{~nm})$ & $1.8 \mathrm{~V}$ and $0.44 \mathrm{~mA} / \mathrm{cm}^{2}\left(\mathrm{AM} 1.5 ; 100 \mathrm{~mW} / \mathrm{cm}^{2}\right)$ & $\begin{array}{l}2010 \\
\text { Tsai }\end{array}$ & {$[37]$} \\
\hline $\begin{array}{l}\text { p-GaN/Al } \mathrm{Al}_{0.14} \mathrm{Ga}_{0.86} \mathrm{~N}-\mathrm{In}_{0.21} \mathrm{Ga}_{0.79} \mathrm{~N} \mathrm{SL} / \mathrm{n}-\mathrm{GaN} \\
\text { (MOVPE) }\end{array}$ & $0.21(42 \mathrm{~nm})$ & $2.1 \mathrm{~V}$ and $0.84 \mathrm{~mA} / \mathrm{cm}^{2}(\mathrm{AM} 1.5)$ & $\begin{array}{l}2010 \\
\text { Yang }\end{array}$ & {$[38]$} \\
\hline p-GaN/InGaN-GaN MQW/n-GaN (MOVPE) & $0.35(36 \mathrm{~nm})$ & $\begin{array}{l}1.8 \mathrm{~V} \text { and } 2.56 \mathrm{~mA} / \mathrm{cm}^{2}(\mathrm{AM} 1.5 ; \sim 100 \mathrm{~mW} / \\
\left.\mathrm{cm}^{2}\right)\end{array}$ & $\begin{array}{l}2010 \\
\text { Dahal }\end{array}$ & {$[39]$} \\
\hline p-i-n GaN/InGaN/GaN (MOVPE) & $0.1(250 \mathrm{~nm})$ & $\begin{array}{l}2.23 \mathrm{~V} \text { and } 1.59 \mathrm{~mA} / \mathrm{cm}^{2}(\mathrm{AM} 1.5 ; 155 \mathrm{~mW} / \\
\left.\mathrm{cm}^{2}\right)\end{array}$ & $\begin{array}{l}2010 \\
\text { Kuwahara }\end{array}$ & {$[40]$} \\
\hline GaN/InGaN/GaN SL of InGaN (MOVPE) & $\begin{array}{l}0.17 / 0.07 \\
(240 \mathrm{~nm})\end{array}$ & $\begin{array}{l}1.78 \mathrm{~V} \text { and } 3.08 \mathrm{~mA} / \mathrm{cm}^{2}(\mathrm{AM} 1.5 ; 155 \mathrm{~mW} / \\
\left.\mathrm{cm}^{2}\right)\end{array}$ & $\begin{array}{l}2011 \\
\text { Kuwahara }\end{array}$ & {$[41]$} \\
\hline p-i-n GaN/InGaN/GaN (MOVPE) & $0.12(60 \mathrm{~nm})$ & $1.89 \mathrm{~V}$ and $1.06 \mathrm{~mA} / \mathrm{cm}^{2}(\mathrm{AM} 1.5)$ & $\begin{array}{l}2011 \\
\text { Matioli }\end{array}$ & {$[42]$} \\
\hline $\begin{array}{l}\text { p-i-n GaN/InGaN/GaN Single or Graded In- } \\
\text { GaN layer (MOVPE) }\end{array}$ & $\begin{array}{l}0.0 \text { to } 0.11 \\
(200 \mathrm{~nm})\end{array}$ & $1.33 \mathrm{~V}$ and $0.59 \mathrm{~mA} / \mathrm{cm}^{2}(\mathrm{AM} 1.5)$ & $\begin{array}{l}2011 \\
\text { Lee }\end{array}$ & {$[43]$} \\
\hline p-i-n GaN/InGaN/GaN (MBE) & $0.11(90 \mathrm{~nm})$ & $1.75 \mathrm{~V}$ and $1.11 \mathrm{~mA} / \mathrm{cm}^{2}(\mathrm{AM} 0)$ & $\begin{array}{l}2011 \\
\text { Lang }\end{array}$ & {$[44]$} \\
\hline p-i-n GaN/InGaN/GaN (MOVPE) & $\begin{array}{l}0.108 \\
(200 \mathrm{~nm})\end{array}$ & $2.0 \mathrm{~V}$ and $0.83 \mathrm{~mA} / \mathrm{cm}^{2}(\mathrm{AM} 1.5)$ & $\begin{array}{l}2011 \\
\text { Shim }\end{array}$ & {$[45]$} \\
\hline p-GaN/InGaN-GaN MQW/n-GaN (MOVPE) & $0.23(25 \mathrm{~nm})$ & $2.05 \mathrm{~V}$ and $1.09 \mathrm{~mA} / \mathrm{cm}^{2}$ (AM1.5) & $\begin{array}{l}2011 \\
\text { Lee }\end{array}$ & {$[46]$} \\
\hline
\end{tabular}


な改善が必要である. 特に, Fig. 11からわかるように, こ の太陽電池では直列抵抗が大きいために, 短絡電流, 曲線因 子が極端に小さくなっている。これは，p-GaNの抵抗が高 いことが主要な原因である.なお，Fig. 11では遮光時と光 照射時の電流密度一電圧特性が大きく異なるが，これは $\mathrm{p}$ InGaN や p-GaN が光伝導性を有することを示しているもの と考えられる.

Sandwich type 素子に関しても，現在，In 組成約 0.3 まで の InGaN を用いた検討が進められており，この構造の太陽 電池に损いて窒化物半導体として最高の変換効率約 $3 \%$ 実 現されている39,41)．性能のさらなる向上のためには In 組成 をさらに増大させる必要があるが，この構造では，InGaN 層が格子緩和しないためにはその厚さを臨界膜厚以下にしな ければならないという制約があり，光吸収層の In 組成を増 すほど，臨界膜厚が小さくなるため膜厚をより小さくしなけ ればならないという矛盾が存在する。

上記のように, InGaN では In 組成 0.4 程度までの材料で $\mathrm{p}$ 型化が実現され，一方，InAlNでは $\mathrm{p}$ 型化はかなり困難で

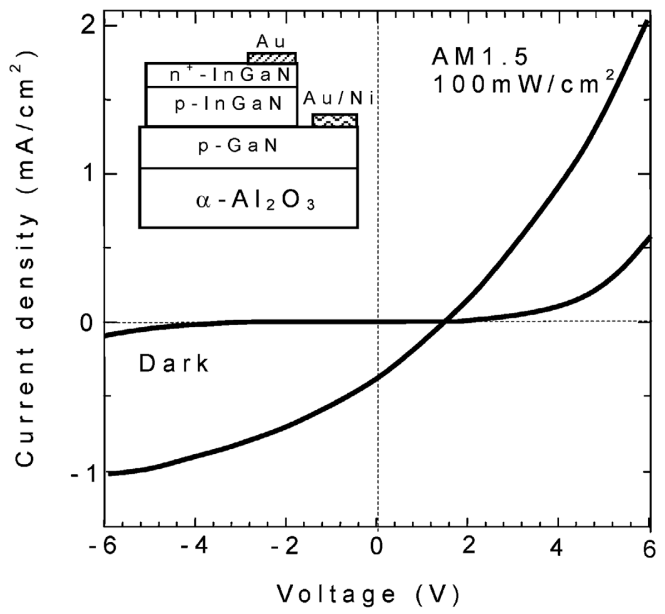

Fig. $11 \mathrm{I}-\mathrm{V}$ characteristics and schematic cross-sectional view for a $\operatorname{In}_{0.25} \mathrm{Ga}_{0.75} \mathrm{~N}$ homojunction device in the dark and under AM1.5, $100 \mathrm{~mW} / \mathrm{cm}^{2}$ illumination.

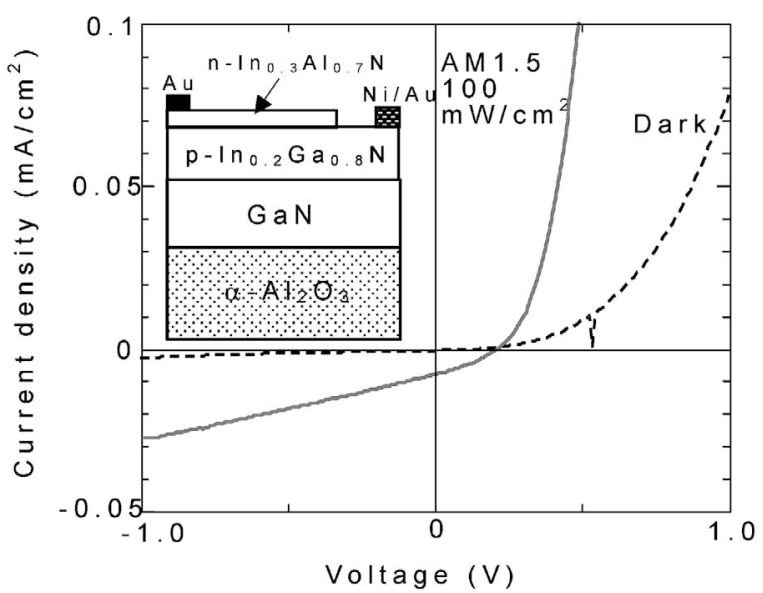

Fig. 12 Schematic cross-sectional view and $\mathrm{I}-\mathrm{V}$ characteristics for a $\mathrm{n}-\mathrm{In}_{0.3} \mathrm{Al}_{0.7} \mathrm{~N} / \mathrm{p}-\mathrm{In}_{0.2} \mathrm{Ga}_{0.8} \mathrm{~N}$ hetero-structure in the dark and under AM1.5, $100 \mathrm{~mW} / \mathrm{cm}^{2}$ illumination.
あることから, n-InAlN/p-InGaN ヘテロ構造素子の作製を 検討した例47)がある. Fig. 12に作製された素子の構造と電 流一電圧特性を示す。ここでは， $\mathrm{n}-\mathrm{In}_{0.3} \mathrm{Al}_{0.7} \mathrm{~N} / \mathrm{p}-\mathrm{In}_{0.2} \mathrm{Ga}_{0.8} \mathrm{~N}$ 構造素子が検討された. Fig. 12の結果からわかるように， ホモ接合素子24)に比べて開放端電圧, 短絡電流ともに劣っ ているが，一応，ヘテロ構造素子として初めて光応答が確認 されている．特性の向上のためには, InGaN, InAlN 両膜の 高品質化とともに, InGaN/InAlN 界面特性の改善が重要で ある。

Table 1, 2 の結果からわかるように, 従来の太陽電池と比 較した場合，単一接合の $\mathrm{InN}$ 系太陽電池技術の現状はかな り低いと言わざるを得ない。その原因としては，光吸収層で ある InGaN の In 組成が約 $0.3\left(\mathrm{E}_{\mathrm{g}} \approx 2.3 \mathrm{eV}\right)$ であるというこ とである，そのために，発生電流も小さく，従って，变換効 率も低い. In 組成 0.3 は 10 接合タンデム太陽電池（Fig. 2 ) でのトップセルの材料にほぼ匹敵するもので，このサブセル のみで高効率化をねらうのは無理である，別の見方をすれ ば，現状はようやく 10 接合タンデム太陽電池のトップセル が実現されたという状況であって, 今後, タンデム化のため にさらに In 組成の高いサブセルの実現を図って行かなけれ ばならない。これまでの In 組成 $0 \sim 0.3$ InGaN セルの検 討でも，In 組成の増加とともに開放端電圧や短絡電流密度 の低下という問題がみられており，高 In 組成の InGaN セル 作製の前途は決して容易ではないと考えられる. 従って, $\mathrm{InN}$ 系タンデム太陽電池の実現には, In-rich InGaN, InN の 薄膜成長に対するブレークスルー技術の開発が不可欠のよう に思われる。

\section{4. まとめおよび今後の課題}

$0.7 \sim 2.5 \mathrm{eV}$ の間の任意のバンドギャップが実現できるこ ととなった InGaN, InAlN が将来の高効率タンデム太陽電池 材料として一躍注目されるようになった。これら InN 系窒 化物混晶半導体太陽電池の研究の現状は, In 組成 $0 \sim 0.3 の$ InGaN を用いた太陽電池が実現されている段階であり，単 一接合太陽電池として既存の太陽電池と競合できる段階では ない，現状は，謂わば，10接合タンデム太陽電池のトップ

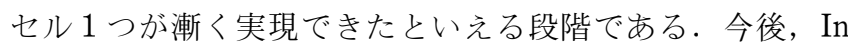
組成 $0.3 \sim 1$ の InGaN のサブセルの作製を検討しそれらのタ ンデム化を検討する必要があるが，そのためには薄膜成長に 対するブレークスルー技術の開発が不可欠であろう.

\section{謝辞}

本研究の一部は, 科学研究費補助金特定領域研究「窒化物 光半導体のフロンティア一材料潜在能力の極限発現一」なら びにJST-CREST「太陽光を利用した独創的クリーンエネ ルギー生成技術の創出」の支援のもとに行われた．有益なご 討論をいただいた福井大学大学院工学研究科 橋本明弘教 授, 福井大学産学官連携本部 杉田憲一博士研究員ならびに 大阪市立大学大学院工学研究科 重川直輝教授に感謝致しま す。 


\section{〔文献〕}

1) V. Yu. Davydov, A. A. Klochikhin, V. V. Emtsev, S. V. Ivanov, V. V. Vekshin, F. Bechstedt, J. Furthmüller, H. Harima, A. V. Mudryi, A. Hashimoto, A. Yamamoto, J. Aderhold, J. Graul and E. E. Haller: Phys. Stat. Sol. (b), 230 (2002) R4.

2) A. Yamamoto, Md. R. Islam, T.-T. Kang and A. Hashimoto: Phys. Stat. Sol. (c), 7 (2010) 1309.

3) A. G. Bhuiyan, K. Sugita, A. Hashimoto and A. Yamamoto: IEEE J. Photovoltaics 2 (2012) 276.

4) N. H. Karam, R. R. King, M. Haddad, J. H. Ermer, H. Yoon, H. L. Cotal, R. Sudharsanan, J. W. Eldredge, K. Edmondson, D. E. Joslin, D. D. Krut, M. Takahashi, W. Nishikawa, M. Gillanders, J. Granata, P. Hebert, B. T. Cavicchi and D. R. Lillington: Sol. Energy Mater. Sol. Cells, 66 (2001) 453.

5) A. Bett: Abstracts of International Symposium on Innovative Solar Cells 2009, Tokyo (2009) p. 36.

6) J. F. Geisz, S. Kurtz, M. W. Wanlass, J. S. Ward, A. Duda, D. J. Friedman, J. M. Olson, W. E. McMahon, T. E. Moriarty, J. T. Kiehl, M. J. Romero, A. G. Norman and K. M. Jones: Proc. of $33^{\text {rd }}$ IEEE PVSC, San Diego (2008) No. 121.

7) M. A. Green, K. Emery, Y. Hishikawa, W. Warta and E. D. Dunlop: Prog. Photovolt: Res. Appl., 19 (2011) 565.

8) D. J. Friedman, J. F. Geisz and J. M. Olsen: J. Cryst. Growth, 195 (1998) 409.

9) J. Wu, W. Walukiewicz, K. M. Yu, J. W. Ager III, E. E. Haller, H. Lu and W. J. Schaff: Appl. Phys. Lett., 80 (2002) 4741.

10) M. Horie, K. Sugita, A. Hashimoto and A. Yamamoto: Sol. Energy Mater. Sol. Cells, 93 (2009) 1013.

11) K. Sasamoto, T. Hotta, K. Sugita, A. G. Bhuiyan, A. Hashimoto, A. Yamamoto, K. Kinoshita and Y. Kohji: J. Cryst. Growth, 318 (2011) 492.

12) J. W. Ager III, L. A. Reichertz, K. M. Yu, W. J. Schaff, T. L. Williamson, M. A. Hoffbauer, N. M. Haegel and W. Walukiewicz: Proc. 33rd IEEE Photovoltaic Specialists Conference, San Diego (2008) A1-31.

13) L. Hsu and W. Walukiewicz: J. Appl. Phys., 104 (2008) 024507.

14) A. G. Bhuiyan, A. Mihara, K. Sugita, A. Hashimoto, A. Yamamoto, N. Watanabe, N. Shigekawa and H. Yokoyama: 21st Photovoltaic Science and Engineering Conference, Fukuoka (2011) $2 \mathrm{D}-4 \mathrm{P}-20$.

15) M. Tanaka, M. Yamamoto, T. T. Kang, A. Hashimoto and A. Yamamoto: The 51st TMS Electronic Materials Conference, Pennsylvania (2009) JJ3.

16) Y. Houchin, A. Hashimoto and A. Yamamoto: Phys. Stat. Sol. (c), 5 (2008) 1571.

17) X. Chen, K. D. Matthews, D. Hao, W. J. Schaff, L. F. Eastman, W. Walukiewicz, J. W. Ager and K. M. Yu: Proc. 33rd IEEE Photovoltaic Specialists Conference, San Diego (2008) A7-34.

18) J. Wu, W. Walukiewicz, K. M. Yu, W. Shan, J. W. Ager, E. E. Haller, H. Lu, W. J. Schaff, W. K. Metzger and S. Kurtz: J. Appl. Phys., 94 (2003) 6477.

19) C. Yang, X. Wang, H. Xiao, J. Ran, C. Wang, G. Hu, X. Wang, X. Zhang and J. Li: Phys. Stat. Sol. (a), 204 (2007) 4288.

20) O. Jani, H. Yu, E. Trybus, B. Jampana, I. Ferguson, A. Doolitthe and C. Honsberg: Proc. 22nd European Photovoltaic Solar Energy Conference, Milan (2007) p. 64.

21) X. Chen, K. D. Matthews, D. Hao, W. J. Schaff and L. F. Eastman: Phys. Stat. Sol. (a), 205 (2008) 1103.

22) P. Misra, C. Boney, N. Medelci, D. Starikov, A. Freundlich and A. Bensaoula: Proc. 33rd IEEE Photovoltaic Specialists Conference, San Diego (2008) N12-342.

23) O. Jani, B. Jampana, M. Mehta, H. Yu, I. Ferguson, R. Opila and C. Honsberg: Proc. 33rd IEEE Photovoltaic Specialists Confer ence, San Diego (2008) C1-38.

24) A. Yamamoto, K. Sugita, M. Horie, Y. Ohmura, Md. R. Islam and A. Hashimoto: Proc. 33rd IEEE Photovoltaic Specialists Conference, San Diego (2008) G5-54.

25) X.-M. Cai, S.-W. Zeng and B.-P. Zhang: Electron. Lett., 45 (2009) 1266.

26) X.-M. Cai, S.-W. Zeng and B.-P. Zhang: Appl. Phys. Lett., 95 (2009) 173504.

27) B. R. Jampana, A. G. Melton, M. Jamil, N. N. Faleev, Robert L. Opila, I. T. Ferguson and C. B. Honsberg: IEEE Electron Device Lett., 31 (2010) 32.

28) C. Boney, I. Hernandez, R. Pillai, D. Starikov, A. Bensaoula, M. Henini, M. Syperek, J. Misiewicz and R. Kudrawiec: Phys. Stat. Sol. (c), 8 (2011) 2466.

29) O. Jani, I. Ferguson, C. Honsberg and S. Kurtz: Appl. Phys. Lett., 91 (2007) 132117.

30) C. J. Neufeld, N. G. Toledo, S. C. Cruz, M. Iza, S. P. DenBaars and U. K. Mishra: Appl. Phys. Lett., 93 (2008) 143502.

31) X. Zheng, R.-H. Horng, D.-S. Wuu, M.-T. Chu, W.-Y. Liao, M.-H. Wu, R.-M. Lin and Y.-C. Lu: Appl. Phys. Lett., 93 (2008) 261108.

32) R. Dahal, B. Pantha, J. Li, J. Y. Lin and H. X. Jiang: Appl. Phys. Lett., 94 (2009) 063505.

33) J.-K. Sheu, C.-C. Yang, S.-J. Tu, K.-H. Chang, M.-L. Lee, W.C. Lai and L.-C. Peng: IEEE Electron Device Lett., 30 (2009) 225.

34） M.-J. Jeng, Y.-L. Lee and L.-B. Chang: J. Phys. D: Appl. Phys., 42 (2009) 105101.

35) R.-H. Horng, S.-T. Lin, Y.-L. Tsai, M.-T. Chu, W.-Y. Liao, M.H. Wu, R.-M. Lin and Y.-C. Lu: IEEE Electron Device Lett., 30 (2009) 724.

36) K. Y. Lai, G. J. Lin, Y.-L. Lai, Y. F. Chen and J. H. He: Appl. Phys. Lett., 96 (2010) 081103.

37) C.-L. Tsai, G.-S. Liua, G.-C. Fana and Y.-S. Leea: Solid-State Electron., 54 (2010) 541.

38) C. C. Yang, J. K. Sheu, X.-W. Liang, M.-S. Huang, M. L. Lee, K. H. Chang, S. J. Tu, F.-W. Huang and W. C. Lai: Appl. Phys. Lett., 97 (2010) 021113.

39) R. Dahal, J. Li, K. Aryal, J. Y. Lin and H. X. Jiang: Appl. Phys. Lett., 97 (2010) 073115.

40) Y. Kuwahara, T. Fujii, Y. Fujiyama, T. Sugiyama, M. Iwaya, T. Takeuchi, S. Kamiyama, I. Akasaki and H. Amano: Appl. Phys. Express, 3 (2010) 111001.

41) Y. Kuwahara, T. Fujii, T. Sugiyama, D. Iida, Y. Isobe, Y Fujiyama, Y. Morita, M. Iwaya, T. Takeuchi, S. Kamiyama, I. Akasaki and H. Amano: Appl. Phys. Express, 4 (2011) 021001.

42) E. Matioli, C. Neufeld, M. Iza, S. C. Cruz, Ali A. Al-Heji, Xu Chen, Robert M. Farrell, S. Keller, S. DenBaars, U. Mishra, S. Nakamura, J. Speck and C. Weisbuch: Appl. Phys. Lett., 98 (2011) 021102.

43) H. C. Lee, Y. K. Su, W. H. Lan, J. C. Lin, K. C. Huang, W. J. Lin, Y. C. Cheng and Y. H. Yeh: IEEE Photonics Tech. Lett., 23 (2011) 347.

44) J. R. Lang, C. J. Neufeld, C. A. Hurni, S. C. Cruz, E. Matioli, U. K. Mishra and J. S. Speck: Appl. Phys. Lett., 98 (2011) 131115.

45) J.-P. Shim, M. Choe, S.-R. Jeon, D. Seo, T. Lee and D.-S. Lee: Appl. Phys. Express, 4 (2011) 052302.

46) Y.-J. Lee, M. H. Lee, C.-M. Cheng and C.-H. Yang: Appl. Phys. Lett., 98 (2011) 263504.

47) K. Sugita, T. Hotta, M. Tanaka, K. Sasamoto, A. G. Bhuiyan, A. Hashimoto and A. Yamamoto: 9th International Conference on Nitride Semiconductors, Glasgow (2011) No. PD3.18. 